\title{
Incompatibility Properties of the IncFIII/FIV Haemolytic Plasmid pSU316 when Integrated in the Escherichia coli Chromosome
}

\author{
By JESÚS NAVAS, FERNANDO DE LA CRUZ*, JOSÉ C. RODRIGUEZ, \\ ISABEL ANDRÉS, GABRIEL PULGAR AND JOSÉ M. ORTIZ \\ Departamento de Bioquímica, Facultad de Medicina, Polígono de Cazoña s/n, Santander, Spain
}

(Received 5 January 1983; revised 15 February 1983)

\begin{abstract}
The haemolytic plasmid pSU316 is incompatible with members of the IncFIII and IncFIV incompatibility groups. Plasmid pSU307 (pSU316 hlyC::Tn5) was inserted by integrative suppression into the chromosome of JW 112, a temperature-sensitive dnaA mutant of Escherichia coli. The incompatibility properties of this strain (SU51) were studied and it was found that: (1) plasmid pSU306 (pSU316 hlyA : :Tn802) was rapidly lost from strain SU51 both at $30^{\circ} \mathrm{C}$ and $42{ }^{\circ} \mathrm{C}$; (2) the IncFIII plasmid pSU397 (ColB-K 98 : :Tn802) was lost from strain SU51 at $42^{\circ} \mathrm{C}$ but not at $30^{\circ} \mathrm{C}$; and (3) the IncFIV plasmid R124 was stably maintained in strain SU51 at both temperatures. Revertants of pSU307 to the autonomous state could be obtained from SU51. These revertants exerted incompatibility towards the prototype plasmids pSU306, pSU397 and R124 in the same way as pSU307 itself. Thus, strain SU51 provided a suitable method for distinguishing the three different incompatibility determinants of plasmid pSU316.
\end{abstract}

\section{INTRODUCTION}

Plasmid incompatibility is the phenotypic expression of the inability of two plasmids to be stably maintained in the same bacterial cell line. Plasmid incompatibility has been used as a criterion for plasmid classification, particularly in epidemiological studies (Datta, 1979; Sasakawa et al., 1980). Also, incompatibility is a manifestation of the mechanisms of control of plasmid replication and partitioning (Lane, 1981; Nordström et al., 1980; Seelke et al., 1982; Timmis et al., 1981) and is often used as a tool for analysing these processes.

The $\alpha$-haemolytic plasmid pSU316 is particularly interesting because it is incompatible with representatives of both the IncFIII (represented by ColB-K98) and IncFIV (represented by R124) groups (de la Cruz et al., 1979). The incompatibility status of these two groups is controversial because their members have been reported to show incompatibility reactions against members of other F incompatibility groups (Gasson \& Willetts, 1975; Săsărman et al., 1980). Furthermore, hybridization experiments showed that plasmid pSU316 had a similar degree of homology to ColB-K98 and R124 as it did to the compatible F-like plasmids R386 (IncFI) and R1 (IncFII) (de la Cruz et al., 1980a).

This work describes a genetic characterization of the incompatibility determinants of plasmid pSU316. Plasmid pSU316 was inserted in the chromosome of a dnaA-ts mutant of Escherichia coli by integrative suppression (Nishimura et al., 1971) and the incompatibility properties of the plasmid studied in the integrated state. In this way, it has been possible to distinguish between incompatibility reactions specific for IncFIII, IncFIV and the presumptive replicon-specific incompatibility of plasmid pSU316.

\section{METHODS}

Bacterial strains and plasmids. The strains and plasmids used are described in Tables 1 and 2, respectively. Genetic experiments. The techniques used for bacterial growth, conjugation and incompatibility testing have been described previously (de la Cruz et al., 1979). Experiments designed to detect the switch-off of replication of

Abbreviations: $\mathrm{Cb}$, carbenicillin; $\mathrm{Km}$, kanamycin; Nal, nalidixic acid; Rif, rifampicin; Sm, streptomycin. 
Table 1. Escherichia coli K12 strains used

\begin{tabular}{ll}
\multicolumn{1}{c}{ Strain } & \multicolumn{1}{c}{ Relevant genotype } \\
EC185 & $\mathrm{F}^{-}$prototroph gyrA \\
DF110 & $\mathrm{F}^{-}$lac pro thi rpsL \\
W3110 Rif & $\mathrm{F}^{-}$prototroph rpoB \\
J53-1 & $\mathrm{F}^{-}$pro met gyrA \\
JW112 & $\mathrm{F}^{-}$lac rpsL dnaA508 \\
UB5201 & $\mathrm{F}^{-}$pro met gyrA recA56 \\
UB1780 & $\mathrm{F}^{-}$pro met gyrA recA56 bla $(\mathrm{Tn} 802)$ \\
SU51 & JW112: :pSU307
\end{tabular}

\author{
Source/Reference \\ Authors' laboratory collection \\ Authors' laboratory collection \\ Authors' laboratory collection \\ Authors' laboratory collection \\ Wechsler \& Gross (1971) \\ Bennett \& Richmond (1976) \\ Bennett \& Richmond (1976) \\ This work
}

Table 2. Plasmids used

\begin{tabular}{|c|c|c|c|c|}
\hline Plasmids & Properties/Origin & Relevant phenotype & $\begin{array}{l}\text { Size } \\
(\mathrm{kb})\end{array}$ & Reference \\
\hline pSU316 & Wild-type Hly plasmid & $\mathrm{Hly}^{+} \mathrm{Tra}^{+}$IncFIII/FIV & 77 & de la Cruz et al. (1979) \\
\hline pSU306 & pSU316 (hlyA:: Tn802) & $\mathrm{Ap}^{r} / \mathrm{Cb}^{\mathrm{r}} \mathrm{Tra}^{+}$IncFIII/FIV & 82 & $\begin{array}{l}\text { de la Cruz et al. (1979) } \\
\text { and this work }\end{array}$ \\
\hline pSU307 & pSU316 (hlyC::Tn5) & $\mathrm{Km}^{r} \mathrm{Tra}^{+}$IncFIII/IV & 82 & This work \\
\hline ColB-K98 & Wild-type Col plasmid & $\mathrm{Cba}^{+} \mathrm{Tra}^{+}$IncFIII & 70 & Frydman \& Meynell (1969) \\
\hline pSU397 & ColB-K98:: Tn 802 & $\mathrm{Ap}^{r} / \mathrm{Cb}^{\mathrm{r}} \mathrm{Cba}^{+} \mathrm{Tra}^{+}$IncFIII & 75 & This work \\
\hline R 124 & Wild-type R plasmid & $\mathrm{Tc}^{r} \mathrm{Tra}^{+}$IncFIV & 124 & Hedges \& Datta (1972) \\
\hline pSU307/8 & Plasmid revertant from SU51 & $\mathrm{Km}^{\mathrm{r}} \mathrm{Tra}^{+}$IncFIII/IV & 71 & This work \\
\hline
\end{tabular}

the integratively supressed strain SU51 and plasmid-containing derivatives were carried out as described by Molin \& Nordström (1980). Basically, strains growing exponentially in Penassay broth (AM3; Difco) at $30^{\circ} \mathrm{C}$ were diluted into pre-warmed $\left(42{ }^{\circ} \mathrm{C}\right)$ medium, and growth was followed spectrophotometrically in a Spectronic 20 colorimeter (Bausch \& Lomb) at $600 \mathrm{~nm}$.

Genetic labelling of plasmids with transposons. Plasmids were labelled with transposons $\operatorname{Tn} 802$ and $\operatorname{Tn} 5$ by the following tri-parental mating technique. Strain UB1780 (Bennett \& Richmond, 1976) carrying Tn802, and strain ECS605 carrying Tn 5 (A. Pühler, personal communication) were mixed with strains carrying the plasmid to be labelled and the final recipient, DF110 (streptomycin-resistant; $\mathrm{Sm}^{\mathrm{r}}$ ), and incubated at $37^{\circ} \mathrm{C}$ for about $18 \mathrm{~h}$. Transconjugants were selected on streptomycin ( $300 \mu \mathrm{g} \mathrm{ml}^{-1}$; Compañía Española de Penicilina y Antibióticos) and either carbenicillin $\left(\mathrm{Cb} ; 500 \mu \mathrm{g} \mathrm{ml}^{-1}\right.$; Beechams) for pSU316 : :Tn802 and ColB-K $98:: \operatorname{Tn} 802$ or kanamycin (Km; $50 \mu \mathrm{g} \mathrm{ml}^{-1}$; Laboratorios Lefa S.A.) for pSU316::Tn5.

A total of $48 \mathrm{Sm}^{r} \mathrm{Km}^{r}$ colonies were isolated from the EC185(pSU316) $\times$ ECS605 $\times$ DF110 mating; 20 were $\mathrm{Hly}^{-}$. One derivative was chosen because it showed a high transfer frequency $\left(4 \times 10^{-4} \mathrm{Km}^{\mathrm{r}}\right.$ transconjugants per donor cell in $1 \mathrm{~h}$ crosses). The physical structure of the pSU316::Tn 5 plasmid present (called pSU307) was determined by restriction endonuclease analysis (Fig. 1). A ColB-K 98 : :Tn 802 plasmid (called pSU397) was constructed in a similar fashion.

Integrative suppression of the dnaA-ts508 mutation. Plasmid pSU307 was transferred to strain JW112 (Smr) by conjugation at $30^{\circ} \mathrm{C}$. Transconjugant $\mathrm{Km}^{\mathrm{r}} \mathrm{Sm}^{\mathrm{r}}$ colonies were isolated, grown at $30^{\circ} \mathrm{C}$, and plated on Penassay (Antibiotic Medium no. 3; Difco) agar plates at $30^{\circ} \mathrm{C}$ and $42{ }^{\circ} \mathrm{C}$. The efficiency of plating at $42^{\circ} \mathrm{C}$ in relation to that at $30^{\circ} \mathrm{C}$ was about $10^{-5}$. Individual colonies that grew at $42^{\circ} \mathrm{C}$ were purified and checked for $\mathrm{Km}$ and for the presence of plasmids by a screening technique (Kitts et al., 1982). One strain (SU51) was chosen for further study because the following tests indicated that it carried pSU307 integrated in its chromosome. (1) No plasmid band was detectable when DNA from cleared lysates of SU51 was analysed by agarose gel electrophoresis. (2) The $\mathrm{Km}^{\mathrm{r}}$ determinant was not transferred at a detectable frequency $\left[<10^{-8}\right.$ compared to $3 \times 10^{-3} \mathrm{~K} \mathrm{~m}^{\mathrm{r}}$ transconjugants per recipient in JW112(pSU307) control matings]. (3) A ${ }^{32}$ P-labelled RNA probe obtained by transcription of pSU307 DNA in vitro (de la Cruz et al., 1980b) was tested for hybridization with EcoRI-cleaved DNA prepared from SU51 by the method of Southern (1975). The hybridization pattern corresponded to the EcoRI bands of pSU307 itself (data not shown). (4) Plasmid pSU306 is stably maintained in strain JW 112, but not in strain SU51 (Table 3). (5) Revertants of SU51 carrying pSU307 in the autonomous state were obtained from SU51 after prolonged growth at $30{ }^{\circ} \mathrm{C}$ (see below).

Isolation of revertants of SU51. In order to obtain revertants of SU51 with pSU307 in the autonomous state, the strain was grown for many generations at $30^{\circ} \mathrm{C}$ by repeated subculture in fresh medium. This culture was mixed with strain W3110 Rifr. After mating for $6 \mathrm{~h}$ at $30^{\circ} \mathrm{C}, \mathrm{Km}^{\mathrm{r}} \mathrm{Rif}^{\mathrm{r}}$ transconjugants were isolated at a frequency of about $3 \times 10^{-6}$ per donor cell. 
Biophysical and biochemical techniques. The method of Kitts et al. (1982) was used to check for the presence of plasmids and measure their size. Plasmid DNA was purified from Triton X-100 cleared lysates by precipitation with polyethylene glycol, followed by caesium chloride/ethidium bromide density-gradient centrifugation as described previously (de la Cruz et al., 1980 b). The methods used for cleavage of DNA with restriction enzymes, for agarose gel electrophoresis, preparation of ${ }^{32} \mathrm{P}$-labelled RNA from plasmid DNA in vitro, hybridization of labelled RNA with DNA on nitrocellulose filters and autoradiography have all been described previously (de la Cruz et al., 1979, 1980b).

\section{RESULTS}

\section{Genetic labelling of plasmids}

Plasmids pSU316 and ColB-K98 can be identified readily because they produce $\alpha$-haemolysin and colicin, respectively, but these markers cannot be selected. In order to achieve positive and mutually distinguishable selection, the plasmids were labelled by transposon insertion. Thus, pSU316 was labelled with Tn5, to produce plasmid pSU307 (Fig. 1). In addition, pSU306 (pSU316: :Tn802) was already available (de la Cruz et al., 1979; Fig. 1). As can be seen in Fig. 1, no detectable deletion or any other rearrangement accompanied the insertions in pSU306 and pSU307.

Plasmid ColB-K98 is about $70 \mathrm{~kb}$ in length. The insertion of $\mathrm{Tn} 802$ that produced plasmid pSU397 caused an increase in size of $5 \mathrm{~kb}$.

\section{Incompatibility properties of SUS1}

Strain SU51 was constructed as described in Methods. In order to analyse the incompatibility properties of plasmid pSU307 in the integrated state, derivatives of SU51 were constructed that contained plasmid pSU306, pSU397 or R124. The inheritance of these plasmids was analysed (Table 3). Plasmid pSU306 was very unstable in strain SU51 at both $30^{\circ} \mathrm{C}$ and $42^{\circ} \mathrm{C}$. On the other hand, plasmid R124 was completely stable at both temperatures. Plasmid pSU 397 was stable at $30{ }^{\circ} \mathrm{C}$ but was lost at high rates after growth at $42{ }^{\circ} \mathrm{C}$. The incompatibility results obtained with pSU307 in the autonomous state are also included in Table 3 for comparison.

It has been described that plasmids which consist of multiple replication regions can be stably co-maintained in strains containing an incompatible plasmid integrated in the chromosome (Molin \& Nordström, 1980). In these cases, what is affected is the growth of the strain itself; this phenomenon is known as switch-off of replication. Thus, we tested whether derivatives of strain SU51 containing either R124 on pSU397 had their growth impaired by the presence of these plasmids. It was shown that, after a shift to $42^{\circ} \mathrm{C}$, strain SU51(R124) had a doubling time of $58 \mathrm{~min}$, almost identical to that of strain SU51 itself (57 min). However, strain SU51(pSU397) grew at $42{ }^{\circ} \mathrm{C}$ with a doubling time of $76 \mathrm{~min}$. It can be assumed from these results that pSU397, but not R124, causes switch-off of replication of strain SU51.

Three conclusions can be drawn from these results. First, the incompatibility of integrated pSU307 towards R124 is not expressed. Second, the incompatibility of integrated pSU307 towards pSU397 is expressed at $42{ }^{\circ} \mathrm{C}$, but not at $30^{\circ} \mathrm{C}$. Finally, the incompatibility against pSU306, the isogenic plasmid, is expressed at both temperatures.

\section{Incompatibility properties of autonomous plasmid derivatives obtained from strain SU51}

In order to confirm that strain SU51 still contained intact all the incompatibility determinants present in the original plasmid pSU307, revertants of pSU307 to the autonomous state were isolated from SU51. Six independent revertants of strain SU51 carrying pSU307 in the autonomous state were analysed for their plasmid content and structure. All six strains contained a single plasmid. Analysis of the electrophoretic patterns produced by digestion of these plasmid DNA molecules with endonuclease $B g I I I$ showed that these revertants are similar to plasmid pSU307 but have suffered genetic rearrangements during the integration/excision process (Fig. 2). Three types of revertants were obtained. Although their structures have not been investigated in detail, inspection of their restriction patterns suggested the type of genetic rearrangements that had occurred [see Bukhari \& Kamp (1980) for detailed explanations]. Type I revertants have several extra fragments and are probably the result of the acquisition of 

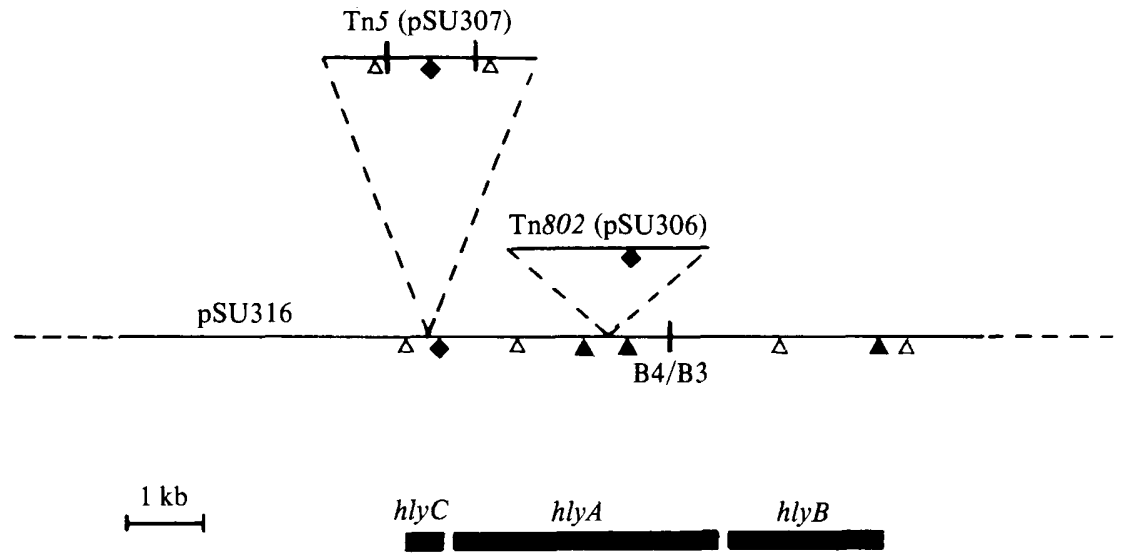

Fig. 1. Restriction map of the hly region of plasmids pSU316, pSU306 (pSU316 hly $A:: \operatorname{Tn} 802$ ) and pSU 307 (pSU316 hlyC::Tn5). The restriction map of pSU316 is known (de la Cruz et al., $1980 \mathrm{~b}$ and unpublished). The sites of insertion of $\operatorname{Tn} 802$ and $\mathrm{Tn} 5$ were mapped after single and double digestions with the relevant enzymes (data not shown). The position of the hly genes has been taken from Goebel \& Hedgpeth (1982). The restriction enzymes used were $\operatorname{Eco} \mathrm{RI}(\boldsymbol{\Lambda}), \operatorname{HindIII}(\triangle), \operatorname{BamHI}(\bullet)$ and $\operatorname{BgIII}(\mathbf{I})$. B4/B3 indicates the $B g / I I$ site that cleaves between fragments $B g / I I-3(11.5 \mathrm{~kb})$ and $B g I I I-4(8.3 \mathrm{~kb})$ of pSU316. The relative sizes of the sequences corresponding to the insertions of the transposons have been scaled down $(1: 2)$.

Table 3. Incompatibility properties of strain SU5I and derivatives

Percentage incompatibility against:

\begin{tabular}{|c|c|c|c|c|c|c|}
\hline \multirow[b]{2}{*}{ Plasmid } & \multicolumn{2}{|c|}{ SU51* } & \multicolumn{2}{|c|}{ Revertants $\dagger$} & \multicolumn{2}{|c|}{$\operatorname{pSU} 307 \ddagger(t=0)$} \\
\hline & $t=0 \S$ & $t=20$ & $t=0$ & $t=20$ & Resident & Donor \\
\hline $\operatorname{pSU} 306\left\{\begin{array}{l}30^{\circ} \mathrm{C} \\
42{ }^{\circ} \mathrm{C}\end{array}\right.$ & $\begin{array}{r}32 \\
100\end{array}$ & $\frac{100}{-}$ & 98 & 100 & 100 & 100 \\
\hline $\mathrm{R} 124\left\{\begin{array}{l}30^{\circ} \mathrm{C} \\
42^{\circ} \mathrm{C}\end{array}\right.$ & $\begin{array}{l}0 \\
0\end{array}$ & $\begin{array}{l}0 \\
0\end{array}$ & 42 & 86 & 43 & $6 \|$ \\
\hline $\operatorname{pSU} 397\left\{\begin{array}{l}30{ }^{\circ} \mathrm{C} \\
42{ }^{\circ} \mathrm{C}\end{array}\right.$ & $\begin{array}{l}0 \\
0\end{array}$ & $\begin{array}{r}0 \\
100\end{array}$ & 2 & 14 & 4 & 40 \\
\hline
\end{tabular}

* Derivatives of SU51 containing plasmids pSU306, pSU397 or R124 were constructed by transferring those plasmids to SU51 by conjugation either at $30^{\circ} \mathrm{C}$ or $42^{\circ} \mathrm{C}$ (depending on the temperature at which the incompatibility was to be studied) and selecting for $\mathrm{Sm}^{r}$ and a marker on the plasmid. The figures are the percentages of cells that have lost the marker of the donor plasmid after growth in drug-free medium for 0 or 20 generations $(t)$. In the cases in which the donor plasmid seemed to be stably inherited, its presence was demonstrated by the plasmid screening technique.

† As above, except that strain UB5201 Nal' (pSU307/8) was the recipient. The donor plasmids were present in strain DF110. The incompatibility was studied at $37^{\circ} \mathrm{C}$.

† Doubles were constructed by conjugating derivatives of strain DF110 containing plasmids pSU306, pSU397 or R124 with W3110(pSU307). The incompatibility was studied at $37^{\circ} \mathrm{C}$. The results of crosses performed in both directions (i.e. with pSU307 being either the resident or the donor plasmid) have been recorded. In all cases the resident plasmid was lost except in (\|) in which the donor plasmid (pSU307) was preferentially lost.

$\S$ Plating at $t=0$ involves resuspending in broth the original colonies that were obtained on the selective plates, plating on drug-free plates and replica plating these new colonies on to drug-containing plates. Thus, it is assumed that the loss of the donor plasmid occurs during growth on the non-selective plates.

additional DNA sequences from an adjacent region of the bacterial chromosome. Type II revertants, which lack two fragments and have acquired two new fragments instead, could be the result of inversion or substitution. Type III revertants probably arose after deletion of a segment of pSU307 DNA containing regions of DNA from the pSU307 fragments $B g / \mathrm{II}-3$ $(11.5 \mathrm{~kb})$ and $B g / \mathrm{II}-5(4.5 \mathrm{~kb})$. All the three plasmid types contain the $7 \cdot 2 \mathrm{~kb}$ fragment $B g / \mathrm{II}-4$ of pSU307, which is known to contain the replication region of the plasmid (unpublished results). 


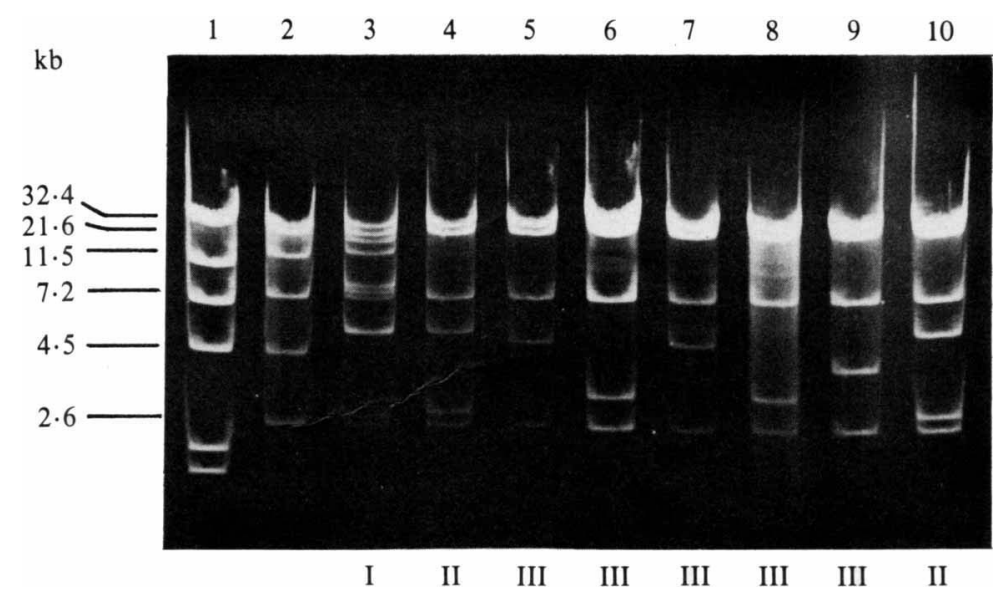

Fig. 2. BgIII restriction endonuclease cleavage patterns of plasmid revertants from strain SU5I. Plasmid DNA was obtained as described in Methods and digested with 2 units of endonuclease $B g I I I$ for $1 \mathrm{~h}$ at $37^{\circ} \mathrm{C}$. The products of such digestions were run in $1 \%(\mathrm{w} / \mathrm{v})$ agarose gels as described previously (de la Cruz et al., 1979). The sizes (in kb) of the $B g / \mathrm{II}$ fragments of pSU307 are indicated on the left-hand side of the Figure. $\lambda$ DNA digested with HindIII (track 1 ) provided fragment size markers. All the other samples were digested with $B g / \mathrm{II}$ : track 2, pSU307; tracks 3-10, DNA obtained from individual $\mathrm{Km}^{\tau}$ transconjugant colonies obtained after the mating SU51 $\times$ W3110 Rif ${ }^{\mathrm{r}}$. Three types of restriction patterns (I, II and III) were obtained.

All these rearrangements involve DNA regions from the site of the Tn5 insertion downstream from the hly genes (see Fig. 1).

One of the type II derivatives (called pSU307/8) was chosen for the incompatibility tests. It was transferred to the rec $A$ strain UB5201 at a frequency of $3 \times 10^{-4} \mathrm{Km}^{\mathrm{r}}$ transconjugants $\mathrm{ml}^{-1}$ after a 90 min mating at $37^{\circ} \mathrm{C}$. Three transconjugant colonies were used to construct doubleplasmid strains carrying pSU307/8 along with either pSU306, pSU397 or R124. The incompatibility tests (Table 3) show that pSU307/8 is incompatible with both pSU397 and R124. Thus, SU51 must harbour the IncFIII and IncFIV incompatibility determinants although they are not expressed normally. The incompatibility between R124 and pSU307 is unusual because it results in highly asymmetric segregation. Thus, pSU307/8 was transferred to strain UB5201(R124) and the incompatibility between these plasmids was studied. It was demonstrated that pSU307/8 (the donor) was lost in $9 \%(t=0$ generations) and $27 \%(t=20$ generations) of the colonies, so that it maintains the asymmetric incompatibility behaviour of pSU307.

\section{DISCUSSION}

F-like plasmids of Enterobacteriaceae have been classified into six incompatibility groups (Datta, 1979; de la Cruz et al., 1980a). The incompatibility determinants of two of them, the IncFI and IncFII groups, have been studied in depth (Lane, 1981; Timmis et al., 1981), but the others have been hardly studied at all. We are interested in IncF determinants because comparison of plasmid replication control regions may shed light on the evolutionary relationships among the F-like plasmids.

When plasmid pSU307 was integrated in the $E$. coli chromosome, at least three kinds of incompatibility determinants were distinguished. The first one, active only against isogenic plasmids such as pSU306, is shown by incompatibility at the permissive temperature. A second, called IncFIII is only active against IncFIII plasmids at the restrictive temperature. The third, the IncFIV incompatibility of pSU307, is only active when both plasmids are autonomous. The dissection of these incompatibility determinants at the molecular level is now being undertaken in our laboratory and results (unpublished) suggest that these three kinds of incompatibility correspond to different DNA sequences present in plasmid pSU307. 
In the case of SU51(pSU397), plasmid pSU397 is stable at $30^{\circ} \mathrm{C}$, but is eliminated at the restrictive temperature, where the integrated plasmid presumably directs replication of the bacterial chromosome. At the permissive temperature, the bacterial origin, and thus the chromosomal machinery for the control of replication, is presumably used (Chandler et al., 1977). Assuming this to be the case for SU51, it is tempting to speculate that the reason for this incompatibility is that pSU 307 and the IncFIII plasmids share a site necessary for replication and/or partition, but do not share a diffusible product (i.e. a repressor) acting as a copy-number control gene product. The repressor will only work on pSU316 derivatives and, therefore, will produce incompatibility against pSU306, but not against pSU397, at the permissive temperature.

The situation found between the integrated pSU307 and R124 is similar to that found where F is unilaterally displaced by IncHI plasmids from strains containing $\mathrm{F}$ in the autonomous but not in the integrated state (Smith et al., 1973). In order to interpret the interactions between pSU316 and R124, the following facts have to be taken into account: (1) R124 retains its incompatibility properties when integrated in the bacterial chromosome (Sasakawa et al., 1980); (2) R124 is stably maintained in strain SU51 both at the permissive and the non-permissive temperatures (this work); (3) R124 is compatible with ColB-K98 (Hedges \& Datta, 1972); (4) when strains are constructed containing R124 and pSU316, both in the autonomous state, pSU316 is selectively eliminated, irrespective of the direction of the cross (de la Cruz et al., 1979); and (5) R124 does not switch-off the replication of SU51 at $42{ }^{\circ} \mathrm{C}$ (this work).

Plasmids may show a complex set of incompatibility reactions for two reasons: firstly, different mechanisms (e.g. control of replication and partitioning) can lead to the expression of incompatibility (as discussed by Novick \& Hoppensteadt, 1978). Secondly, plasmids can carry more than one set of replication/partition systems brought together by the evolutionary history of the element (possibly due to plasmid fusions in the past). The results presented in this work shed some light on the plasmid interactions underlying the expression of the incompatibility reactions shown by plasmid pSU316. In summary, when integrated in the bacterial chromosome, plasmid pSU316 expresses a trans-acting function (such as a copy-number control gene product) which causes elimination of isogenic derivatives, but this trans-acting function neither eliminates IncFIII nor IncFIV plasmids. Elimination of IncFIII plasmids is most probably brought about by competition of cis-acting genes (i.e. sites) necessary for initiation of replication or partitioning as discussed above. This interaction is mutual since pSU397 causes switch-off of SU51 replication. Thus, plasmid pSU316 and IncFIII plasmids share only part of their incompatibility determinants. This phenomenon is very well documented for plasmids belonging to the IncFI group (Bergquist et al., 1982). R124 presents a unilateral incompatibility towards pSU316 which is suppressed when pSU316 is integrated in the bacterial chromosome. This behaviour could be explained if R124 contained two sites controlling initiation of replication and/or partitioning, either of which could be used in order to assure stable inheritance of the plasmid. One of them could interact with plasmid pSU316 when in the autonomous state and thus produce unilateral incompatibility. When integrated in the bacterial chromosome, however, plasmid pSU316 could use the chromosome partition system and therefore the incompatibility against R124 would be suppressed. However, the existing data cannot rule out alternative explanations.

This work was supported by a grant (project no. 0366/81) from the Comisión Asesora de Investigación Científica y Técnica. We are greatly indebted to Dr Tim Foster for correction of the manuscript and to Marta Garcia who typed it.

The authors would like to dedicate this work to Dr A. Gimenez Solves, acknowledging his effort in the promotion of young research workers.

\section{REFERENCES}

BennetT, P. M. \& Richmond, M. H. (1976). Translocation of a discrete piece of DNA carrying an $a m p$ gene between replicons in Escherichia coli. Journal of Bacteriology 126, 1-6.
Bergquist, P. L., Lane, H. E. D., Malcolm, L. \& DownARD, R. A. (1982). Molecular homology and incompatibility in the IncFI plasmid group. Journal of General Microbiology 128, 223-238. 
BukhaRI, A. I. \& KaMP, D. (1980). Genetic rearrangements and DNA cleavage maps. Methods in Enzymology 65, 436-449.

Chandler, M., Silver, L. \& Caro, L. (1977). Suppression of an Escherichia coli dnaA mutation by the integrated $\mathrm{R}$ factor R 100.1 : origin of chromosome replication during exponential growth. Journal of Bacteriology 131, 421-430.

de la CRuz, F., Zabala, J. C. \& Ortiz, J. M. (1979). Incompatibility among $\alpha$-hemolytic plasmids studied after inactivation of the $\alpha$-hemolysin gene by transposition of Tn802. Plasmid 2, 507-519.

de la Cruz, F., Zabala, J. C. \& Ortiz, J. M. (1980a). The molecular relatedness among $\alpha$-hemolytic plasmids from various incompatibility groups. Plasmid 4, 76-81.

de la Cruz, F., Müller, D., Ortiz, J. M. \& Goebel, W. $(1980 b)$. Hemolysis determinant common to Escherichia coli hemolytic plasmids of different incompatibility groups. Journal of Bacteriology 143, $825-833$.

Datta, N. (1979). Plasmid classification: incompatibility grouping. In Plasmids of Medical, Environmental and Commercial Importance, pp. 3-12. Edited by $\mathrm{K}$. N. Timmis \& A. Pühler. Amsterdam: Elsevier-North Holland Biomedical Press.

FRYDMAN, A. \& MEYNELl, E. (1969). Interaction between derepressed F-like R-factors and wild type colicin B factors : superinfection immunity and repressor susceptibility. Genetical Research 14, 315332.

Gasson, M. J. \& Willetts, N. S. (1975). Five control systems preventing transfer of Escherichia coli $\mathrm{K}-12$ sex factor F. Journal of Bacteriology 122, 518-525.

Goebel, W. \& Hedgpeth, J. (1982). Cloning and functional characterization of the plasmid-encoded hemolysin determinant of E. coli. Journal of Bacteriology 151, 1290-1298.

Hedges, R. W. \& Datta, N. (1972). R124 an $f^{+}$R factor of a new compatibility class. Journal of General Microbiology 71, 403-405.

Kitts, P. A., Lamond, A. \& Sherratt, D. J. (1982). Inter-replicon transposition of $\operatorname{Tnl} / 3$ occurs in two sequential genetically separable steps. Nature, London 295, 626-628.

LANE, H. E. D. (1981). Replication and incompatibility of $\mathrm{F}$ and plasmids in the IncFI group. Plasmid 5, $100-126$
Molin, S. \& Nordström, K. (1980). Control of plasmid R1 replication: functions involved in replication, copy number control, incompatibility, and switch-off of replication. Journal of Bacteriology 141, 111-120.

Nishimura, Y., Caro, L., Berg, C. M. \& Hirota, Y. (1971). Chromosome replication in Escherichia coli. IV. Control of chromosome replication and cell division by an integrated episome. Journal of Molecular Biology 55, 441-456.

Nordström, K., Molin, S. \& Aagaard-Hansen, H. (1980). Partitioning of plasmid R1 in Escherichia coli. II. Incompatibility properties of the partitioning system. Plasmid 4, 332-349.

Novick, R. P. \& Hoppensteadt, F. C. (1978). On plasmid incompatibility. Plasmid 1, 421-434.

Sasakawa, C., Takamatsu, N., Danbara, H. \& YoshikAWA, M. (1980). A method of plasmid classification by integrative incompatibility. Plasmid 3, 116-127.

Săsărman, A., Massie, B., Zollinger, M., GagneTellier, H., Shareck, F., Garzon, S. \& Morisset, R. (1980). Naturally occurring R.ColBM plasmids belonging to the IncFIII incompatibility group. Journal of General Microbiology 119, 475-483.

Seelke, R. W., Kline, B. C., Trawick, J. D. \& Ritts, G. D. (1982). Genetic studies of F plasmid maintenance genes involved in copy number control, incompatibility and partitioning. Plasmid 7, 163179.

Smith, H. R., Grindley, N. D. F., Humphreys, G. O. \& ANDERSON, E. S. (1973). Interactions of group H resistance factors with the $\mathrm{F}$ factor. Journal of Bacteriology 115, 623-628.

Southern, E. M. (1975). Detection of specific sequences among DNA fragments separated by gel electrophoresis. Journal of Molecular Biology 98, 503-517.

Timmis, K. N., Danbara, H., Brady, G. \& Lurz, R. (1981). Inheritance functions of group IncFII transmissible antibiotic resistance plasmids. Plasmid 5, 53-75.

WeChSler, J. A. \& Gross, J. D. (1971). Escherichia coli mutants temperature-sensitive for DNA synthesis. Molecular and General Genetics 113, 273-284. 